\title{
How a river course influences the species richness and ecological requirements on two opposite riverbanks in a forest area
}

\author{
Bożenna Czarnecka1* Anna Rysiak', Łukasz Chabudziński² \\ 'Department of Ecology, Faculty of Biology and Biotechnology, Maria Curie-Skłodowska University, Akademicka 19, 20-033 Lublin, Poland \\ ${ }^{2}$ Geoinformation Laboratory, Faculty of Earth Sciences and Spatial Management, Maria Curie-Skłodowska University, Kraśnicka 2c,d, 20-718 Lublin, Poland
}

\begin{abstract}
The goal of the present research was to find correlations between the topographic attributes of a river valley and local ground-floor vegetation and its habitat requirements expressed by ecological indicator values (EIV), using the geographical information systems (GIS), digital elevation model (DEM), and multivariate statistical analysis. We paid special attention to the river course, which determines the differentiation in slope aspects and the amount of solar radiation reaching the ground surface. The model object was an almost latitudinal, ca. 4-km-long break section of the Sopot river, crossing the escarpment zone of the Central Roztocze Highlands, southeastern Poland. The main material comprised species lists (with estimated abundance) for each ca. 200-m-long section, according to the river valley course, separately for the left and right riverbanks, 40 sections altogether, ca. 15000 vegetation records, and physical and chemical soil measurements. A 3-meter resolution DEM was derived from a 1:10 000 topographic map. We calculated the correlations between the topographic attributes of the valley, species richness, and the EIVs for all the species recognized in each section of the valley. We found 241 herb plant species in the ground-floor vegetation of the study area. We did not find significant differences between the two riversides ( $61 \pm 13$ species per one section for the left and $63 \pm 17$ for the right side). Thus, the parallel course of the river valley does not change the species richness on a more "sunny" and more "shiny" riverbank. However, this factor "cooperating" with other topographic attributes of the valley significantly differentiates the shape of species showing various requirements for basic habitat resources: light, moisture, soil trophy, reaction, dispersion, and organic-matter content.
\end{abstract}

Keywords: species diversity; ground-floor vegetation; riparian landscape; ecological indicator values; solar radiation; wetness index; Digital Elevation Model; multivariate analysis

\section{Introduction}

Habitat complexes of river valleys are characterized by considerable heterogeneity defined as variability of spatial and temporal patterns and processes [1]. Environmental heterogeneity of the riparian landscape is a result of interfaces between terrestrial and aquatic ecosystems, i.e. river fluvial activity (erosion, transport, retention of inorganic sediments and nutrients), organic-matter dynamics, climatic factors, and hydrological relationships between the abiotic and biotic elements of the ecosystem [2-8]. The riverine landscapes are usually characterized by specific zonal toposequence of plant communities as well as great biodiversity, despite the rather small proportion of the total watershed area in a given region [9-14].

For the last decades, application of geographical information systems (GIS) and digital elevation models (DEM)

* Corresponding author. Email: bozenna.czarnecka@poczta.umcs.lublin.pl Handling Editor: Zygmunt Dajdok has provided very useful tools for studying the biodiversity indicators and relationships between topographic and ecological characters of different landscapes, including river systems (e.g. [13-18]). The GIS facilitates classification of natural systems based on linking a variety of spatial components or observation results using multivariate canonical analyses [8,14,19-23]. Regardless of the scale of the study, some spatial elements remain unchanged. The basis of the analytical procedures is two groups of topographic attributes calculated from the DEM [24-26]: primary topographic attributes - slope, aspect, planar (or contour), vertical (or profile), and total curvature; and secondary topographic attributes - solar radiation (SRAD), and the topographic wetness index (TWI).

The approach based on "ecological indicator values" (EIV) of plants as predictors of the environment quality has widely developed since the first attempt made by Ellenberg [27], who defined EIVs, which reflect the realized optima for species of Central Europe expressed as ordinal numbers. The EIV system provides a very valuable tool for habitat calibration and recently it has been applied for modeling 
plant distribution at various spatial scales. However, investigations conducted at the regional and landscape levels $[15,22,28-32]$ are still much more common than studies on local sites [14,17,21,33].

Our studies were focused on a break section of a smallscale river valley characterized by an almost latitudinal course of the entire analyzed fragment, which is the main factor determining the slope aspect and, in consequence, the disproportion between the amounts of energy supplied to the right and left banks of the river valley. We assumed that solar radiation reaching the Earth's surface is the most important environmental factor determining species richness and diversity on the two riverbanks. The goal of the present research was to find correlations between the terrain characters of the river valley and local vascular flora and its ecological requirements expressed by the EIVs in the entire valley and on its right and left sides separately, using the GIS, DEM, and multivariate statistical analysis. Finally, we have discussed the usefulness of the GIS and DEM for studying the relationships between the topographic (abiotic) and ecological (biotic) attributes of the riparian vegetation.

\section{Material and methods}

\section{Study area and material collection}

The study area was a break section (i.e. between the 14th and 18 th $\mathrm{km}$ of the river course) of the Sopot river (IV order river), the largest right-side tributary of the upper Tanew river, crossing the escarpment zone of the Central Roztocze Highlands, southeastern Poland (Fig. 1a). The Sopot river is a 24-km-long stream with a catchment area of approximately $122 \mathrm{~km}^{2}$ and discharge varying from 913 to $1638 \mathrm{dm}^{3} \mathrm{~s}^{-1}$. A characteristic feature of the "strict" zone of the river break (over the first $1.1 \mathrm{~km}$ of the study section) is a large slope of the riverbed (19.1\%o); over the length of ca. $4 \mathrm{~km}-5.3 \%$, on average; a large incision of the valley bottom and presence of numerous rock steps and springs, all of which give the valley a mountainous character. In the upper part of the study area the valley was built of Miocene formations and in the lower part - Quaternary formations, on which different types of soils have been evolved $[11,34,35]$. The valley section to be analyzed ( $4 \mathrm{~km}$ long; $80.5 \mathrm{ha}$ ) is wooded in $99.5 \%$ and only slightly transformed by human activity (map at the 1:5000

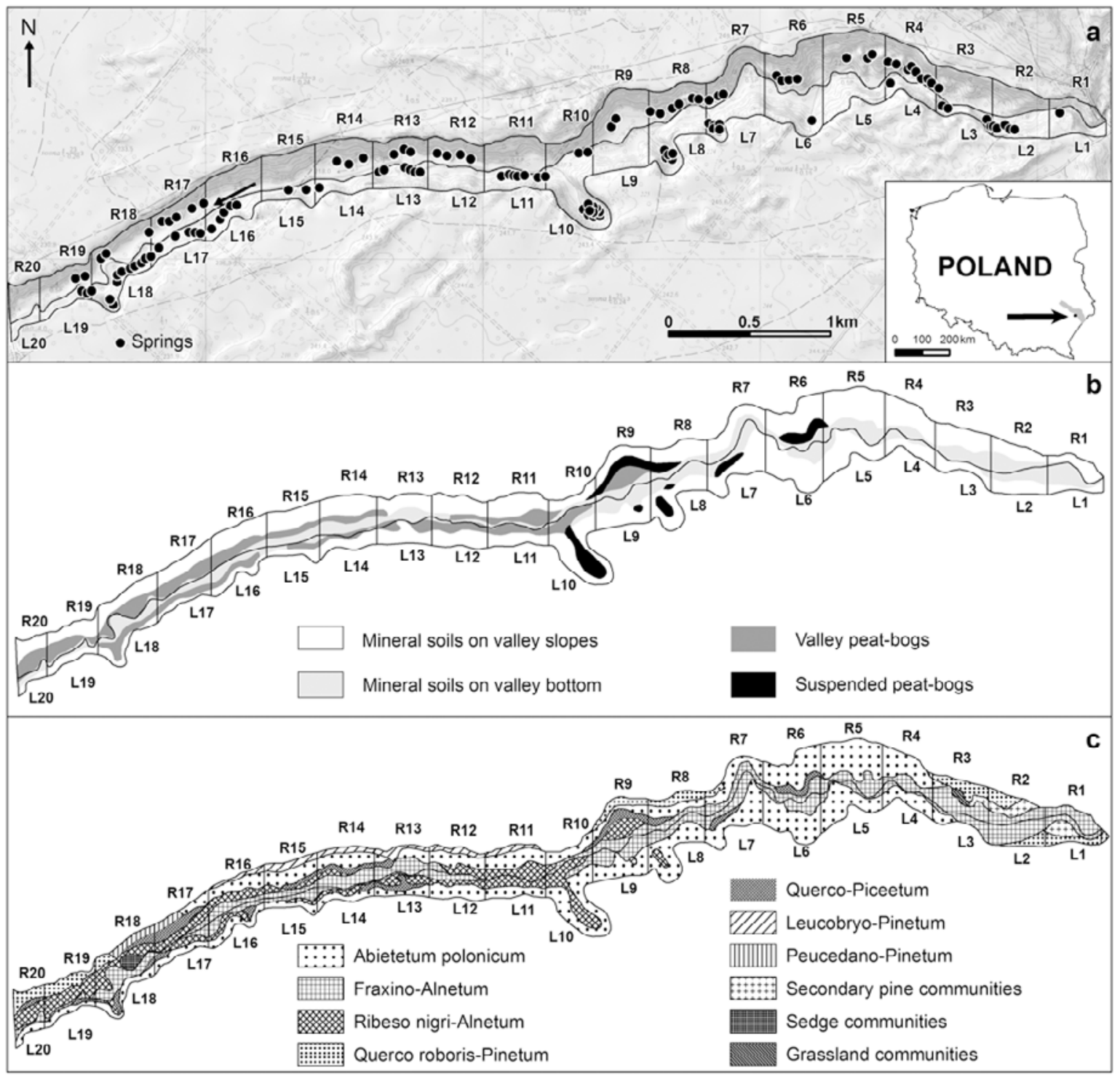

Fig. 1 The study section of the Sopot river valley. a Distribution of springs. b Distribution of soil complexes. c Distribution of plant communities. L1-L20 - left-side sections of the valley. R1-R20 - right-side sections of the valley. Vertical exaggeration $=3$. 
scale from 1998; Czarnecka, unpblished data). The main character of the vegetation landscape of the steep slopes is created by upland mixed fir forest Abietetum polonicum, a community of European importance [36]. The remaining area $(0.5 \%)$ is covered by sedge and meadow vegetation (Tab. 1). The study valley is characterized by zonal arrangement of soil complexes and plant communities (Fig. 1b,c). The most valuable break part of the valley with forests on the slopes and river terrace has been preserved since 1958 in a landscape reserve called "Czartowe Pole" ("The Devil's Field"). The study object was also included in the Natura 2000 network within both types of protected sites: Special Protected Area (PLB 060012) and Special Area of Conservation (PLH 060018).

The main material comprised species lists (with estimated abundance) for each ca. 200-m-long section, according to the river valley course, separately for the left and right riverbanks, 40 sections altogether (Fig. 1). We have established the frequency and abundance of each vascular plant species in the ground-floor vegetation, using a simplified, combined scale, where: 1 - sporadic species; 2 - rare and not-abundant species (covering $<10 \%$ of the section area); 3 - frequent and abundant species (covering $10-50 \%$ of the section area); $4-$ common and very abundant species (covering $>50 \%$ of the section area). To estimate the real habitat conditions in the whole study area and each section and the ecological scale of particular plant species, we also used other field materials: phytosociological relevés in different types of plant communities (60 in total), and soil pits (27 in total) distributed proportionally to the area, and the diversity of the identified communities. Using commonly accepted methods $[37,38]$, the following properties were determined for 140 soil samples: the content of organic matter and/or organic carbon, active acidity, calcium carbonate and basic ions ( $\mathrm{Ca}$, $\mathrm{K}, \mathrm{Na}, \mathrm{Ma}, \mathrm{Fe}, \mathrm{P}$, and $\mathrm{N}$ in the form of ammonia and nitrate).

\section{Analysis of terrain attributes}

Spatial data were obtained from a topographic map at the 1:10 000 scale by successive digitization of contour lines, elevation points, valley edges and their height. For calculation of the terrain attributes, we used tools available in the ArcToolbox of the ArcGIS 10 software and the Spatial Analyst extension. Using the Topo to Raster tool, we generated the DEM and its derivatives with a resolution of $3 \mathrm{~m}$ [39]. Based on the DEM and the derivatives, the following commonly used topographic attributes were calculated [24-26]: primary - slope, aspect, and planar, vertical, and total curvature; and secondary - the SRAD and TWI. Apart from the above-listed attributes, we also took into account additional primary terrain characters: denivelation (elevation gradient), total area, flat area (i.e. $\leq 2^{\circ}$ of terrain slope), and upslope area ( $>2^{\circ}$ of terrain slope) of a given section. Subsequently, each attribute was analyzed for each valley section of the river using the Zonal Statistics tool, with which a statistic was calculated for each zone defined by a zone dataset (in our case, these were particular sections of the valley), based on values from the other datasets (DEM, slope aspect, planar, vertical and total curvature, SRAD, and TWI). A single output value was computed for every zone in the input zone dataset. For detailed description, see Czarnecka and Chabudziński [14].

\section{Statistical analysis}

In the next step, the mean value of specific EIVs in each valley section was calculated using a modified formula for the weighted average [14]:

$$
W_{A}=\frac{\sum_{i=1}^{n}\left(A_{i}^{2} I_{i}\right)}{\sum_{i=1}^{n} A_{i}^{2}}
$$

where: $W_{A}$ - weighted average, $A_{i}$ - abundance of the cover of the $i$-th species in a given section of the valley, $I_{i}$ - ecological indicator value for the $i$-th species, $n$ - number of species in the section.

We calculated the correlations of topographic attributes of the valley, species richness, and the EIVs for all the species in each section. According to the suggestions of some authors $[21,28,40]$, we analyzed the EIVs only for one vegetation layer, i.e. ground-floor vegetation (pteridophytes

Tab. 1 Characteristics of the study area of the Sopot river valley $([34,35]$ and Czarnecka unpblished data).

\begin{tabular}{|c|c|c|c|c|}
\hline Plant community & Area (\%) & Soil types & Active acidity (pH) & $\begin{array}{c}\text { Organic matter/ } \\
\text { humus content }(\%)\end{array}$ \\
\hline Upland mixed fir forest Abietetum polonicum & 46.1 & $\begin{array}{l}\text { Podzolic soil } \\
\text { Rusty-podzolic soil }\end{array}$ & $\begin{array}{l}3.64-5.32 \\
4.07-4.40\end{array}$ & $\begin{array}{l}0.11-0.65 \\
0.23-2.13\end{array}$ \\
\hline Riverside ash-alder forest Fraxino-Alnetum & 21.2 & $\begin{array}{l}\text { Brown pararendzina } \\
\text { Alluvial soil } \\
\text { Gley podzolic soil } \\
\text { Low peat soil }\end{array}$ & $\begin{array}{l}7.57-7.98 \\
5.53-7.73 \\
4.06-8.15 \\
4.46-8.18\end{array}$ & $\begin{array}{r}1.20-2.77 \\
0.21-21.61 \\
0.27-13.19 \\
39.53-80.79\end{array}$ \\
\hline Bog alder forest Ribeso nigri-Alnetum & 14.2 & Low peat soil & $5.34-7.75$ & $18.15-85.76$ \\
\hline Oak-pine mixed forest Querco roboris-Pinetum & 7.0 & Rusty-podzolic soil & $4.56-6.37$ & $0.81-1.09$ \\
\hline Moist mixed coniferous forest Querco-Piceetum & 5.7 & $\begin{array}{l}\text { Low peat soil } \\
\text { Gley podzolic soil }\end{array}$ & $\begin{array}{l}3.51-5.56 \\
4.24-5.49\end{array}$ & $\begin{array}{r}35.98-90.99 \\
6.49-56.18\end{array}$ \\
\hline $\begin{array}{l}\text { Suboceanic pine forest Leucobryo-Pinetum } \\
\text { Subcontinental pine forest Peucedano-Pinetum }\end{array}$ & 3.2 & Podzolic soil & $4.74-6.68$ & $0.10-0.61$ \\
\hline Secondary pine communities & 0.8 & Podzolic soil & $4.00-4.53$ & $0.14-0.93$ \\
\hline Sedge communities & 0.3 & Low peat soil & $5.10-7.11$ & $28.26-77.20$ \\
\hline Grassland communities & 0.2 & Leached brown soil & $5.32-6.42$ & 2.07 \\
\hline
\end{tabular}


and spermatophytes, except for the shrub and tree species). The full data set comprises almost 15000 vegetation records taken during the field survey. We took into account the following 6 indicator values describing the most typical habitat conditions of the species according to Zarzycki et al. [41]: light (L), soil moisture (W), trophy (Tr), soil/ water acidity $(\mathrm{R})$, soil granulometry $=$ dispersion $(\mathrm{D})$, and organic matter content $(\mathrm{H})$. The EIVs used in the analyzed valley were calibrated by adjustment to the range of habitat conditions found during the field and laboratory studies. The continentality $(\mathrm{C})$ and temperature $(\mathrm{T})$ values were purposely not taken into account, as their value is constant in a small study area.

To establish whether particular topographic variables have or do not have normal distribution, we used the Shapiro-Wilk test. Because a majority of the values of the analyzed attributes did not show a normal distribution, Spearman's rank correlation coefficients $(r)$ were calculated between the number of species and the mean value for a specific EIV in each section and all topographic attributes of the valley. The mean and sum value of the primary and secondary topographic attributes were taken into account. The correlation analysis was performed for the entire valley section and separately for both riverbanks, due to the varied slope aspect and terrace asymmetry (cf. Fig. 1). All statistics were calculated with the use of Statistica PL.

To analyze the relationships between weighted averages for the particular EIV of local vascular flora and topographic attributes of the valley, we also used multivariate ordination methods in Canoco version 4.5 [19,20]. According to the length of the gradient from preliminary detrended correspondence analysis (DCA), a linear model was used redundancy analysis (RDA). A manual procedure with 499
Monte Carlo significance permutation tests was used to find the minimum number of statistically significant variables. The eigenvalues and percentages of floristic and topographic variance explained by the first four axes were calculated. Finally, the pattern obtained from the classification was transferred onto a graph with sample groups marked in the RDA. The first two axes were shown on the graph.

\section{Results}

\section{Correlations between species richness and topographic attributes}

In total, we found 241 herb plant species (spermatophytes and pteridophytes) in the ground-floor vegetation of the study area. The average number of species per one section was variable (mean \pm standard deviation $=62 \pm 15$ ) and ranged from 32 (section R1) to 99 (R3). We did not notice significant differences between the two riversides $(61 \pm 13$ for the left, $63 \pm 17$ for the right). Species richness increased significantly with the rise of the total area $(r=0.52)$ and the flat area $(r=0.67)$ of a given section; the correlation with the upslope area was weaker for the total study area $(r=$ $0.34)$, but stronger for the left riverside $(r=0.64$; Tab. 2$)$. The number of species was not correlated with terrain denivelation but it decreased significantly with the mean slope $(r=$ $-0.49)$, CP_mean $(r=-0.36)$, CT_mean $(-0.33<r<-0.48)$ and CT_sum $(-0.50<r<-0.61)$. In turn, species richness was positively correlated with CV_mean $(0.49<r<0.56)$ and CV_sum $(0.57<r<0.58)$.

The lowest number of species ( $\leq 50$ species) was recorded in sections, in which at least two of the following three factors were combined: average slope $>10^{\circ}$, denivelation $>20 \mathrm{~m}$, proportion of flat area $<10 \%$ (sections: $\mathrm{L} 1-3, \mathrm{~L} 19-20$,

Tab. 2 Statistically significant correlation coefficients between topographic attributes and ecological indicator values of ground-floor vegetation in the Sopot river valley and its opposite riverbanks.

\begin{tabular}{|c|c|c|c|c|c|c|c|c|c|c|c|c|c|c|c|c|}
\hline \multirow{3}{*}{$\begin{array}{l}\text { Topographic } \\
\text { attributes }\end{array}$} & \multirow{2}{*}{\multicolumn{3}{|c|}{ Number of species }} & \multicolumn{13}{|c|}{ Ecological indicator values } \\
\hline & & & & \multicolumn{2}{|c|}{$\mathbf{L}$} & \multicolumn{2}{|c|}{$\mathrm{w}$} & \multicolumn{3}{|c|}{$\operatorname{Tr}$} & \multicolumn{2}{|c|}{$\mathbf{R}$} & \multicolumn{2}{|c|}{ D } & \multicolumn{2}{|c|}{$\mathbf{H}$} \\
\hline & All & Left & Right & All & Right & All & Right & All & Left & Right & All & Right & All & Right & All & Right \\
\hline TA & $0.52^{* * *}$ & & & & & & & & $0.48^{*}$ & & & & & & & \\
\hline FA & $0.67^{* * *}$ & & & & & & $0.51^{*}$ & $0.38^{*}$ & & & $0.36^{*}$ & & $0.33^{*}$ & $0.56^{\star *}$ & & $0.53^{*}$ \\
\hline UA & $0.34^{*}$ & $0.64^{* \star}$ & & & $-0.51^{*}$ & & $-0.65^{* *}$ & & $0.48^{*}$ & & & & & $-0.51^{*}$ & & $-0.54^{*}$ \\
\hline DN & & & & $-0.54^{* * *}$ & $-0.80^{* * *}$ & $-0.43^{* *}$ & $-0.70^{* * *}$ & & & $-0.53^{*}$ & & $-0.53^{\star}$ & $-0.45^{* *}$ & $-0.59^{* *}$ & $-0.46^{* *}$ & $-0.59^{* *}$ \\
\hline SL_mean & $-0.49^{\star *}$ & & & $-0.49^{* *}$ & $-0.58^{* *}$ & & $-0.60^{* *}$ & $-0.46^{\star *}$ & & & $-0.49^{* *}$ & & $-0.37^{\star}$ & $-0.52^{\star}$ & & $-0.56^{*}$ \\
\hline CP_mean & $-0.36^{\star}$ & & & & & & & $-0.33^{*}$ & $-0.46^{\star}$ & & $-0.32^{*}$ & & & & & \\
\hline CP_sum & & & & & & & & $-0.35^{*}$ & & & $-0.34^{*}$ & & & & & \\
\hline CV_mean & $0.56^{* * *}$ & $0.49^{*}$ & $0.56^{* *}$ & & & & & & & & & & & & & \\
\hline CV_sum & $0.58^{* * *}$ & $0.58^{*}$ & $0.57^{* *}$ & & $0.46^{*}$ & & & & & & & & & & & \\
\hline CT_mean & $-0.33^{*}$ & & $-0.48^{*}$ & & $-0.63^{* *}$ & & $-0.84^{* * *}$ & & & & & & & $-0.51^{\star *}$ & & $-0.82^{* * *}$ \\
\hline CT_sum & $-0.50^{*}$ & $-0.54^{*}$ & $-0.61^{\star *}$ & & $-0.47^{*}$ & & $-0.72^{* * *}$ & & & & & & & $-0.58^{* *}$ & & $-0.75^{* * *}$ \\
\hline SRAD_mean & & $0.48^{*}$ & $-0.56^{*}$ & & $-0.48^{*}$ & & $-0.64^{\star *}$ & & & & & & & & & $-0.65^{\star *}$ \\
\hline SRAD_sum & $0.46^{* *}$ & $0.69^{* * *}$ & & & & & & & $0.47^{*}$ & & & & & & & \\
\hline TWI_mean & $0.69^{* * *}$ & $0.72^{* * *}$ & $0.63^{* *}$ & $0.37^{*}$ & $0.48^{*}$ & $0.48^{* *}$ & $0.66^{* *}$ & $0.42^{*}$ & & & $0.43^{* *}$ & & $0.47^{* *}$ & 0.59 & $0.46^{* *}$ & $0.66^{\star *}$ \\
\hline TWI_sum & $0.57^{* * *}$ & $0.71^{\star * *}$ & & & & & & & $0.47^{*}$ & & & & & & & \\
\hline
\end{tabular}

Explanations: All - all sections of the valley; Left - left sections of the valley; Right - right sections of the valley; TA - total area; FA flat area; UA - upslope area; DN - denivelation; SL_mean - mean slope; CP_mean - mean planar curvature; CP_sum - sum planar curvature; CV_mean - mean vertical curvature; CV_sum - sum vertical curvature; CT_mean - mean total curvature; CT_sum - sum total curvature; SRAD_mean - mean solar radiation; SRAD_sum - sum solar radiation; TWI_mean - mean topographic wetnes index; TWI_sum - sum topographic wetnes index. Significance level: ${ }^{\star} 0.01<P \leq 0.05 ;{ }^{* *} 0.0001<P \leq 0.01 ;{ }^{* *} P \leq 0.0001$. 
R1-2, R4). The highest species richness ( $\geq 75$ species) was characteristic for sections with the largest proportion of the flat area ( $>20 \%$, in some sections even $>40 \%$ ); in this case, denivelation and the mean slope are less important (L7, L9-10, L16, R9, R18-20). Section R3 is an exception (99 species; mean slope $>10^{\circ}$; flat area $=16.7 \%$ ), as it comprises the only afforested fragment of the valley slope overgrown with grassland community with the share of some thermophilous elements (cf. Fig. 1c).

The vascular ground flora displayed a great number of high correlations between species richness and the secondary topographic attributes for the entire valley or at least for the individual banks. A different effect of the SRAD_mean on the species richness was observed for both riverbanks: positive for the left $(r=0.48)$ and negative for the right one $(r=-0.56)$, i.e. for the bank with domination of the southern and northern aspects and their derivatives, respectively. This is correlated with the disproportion between the amounts of energy reaching the surface of ground-floor layer during vegetation season (April-October) in the right- and left-side sections of the river valley, $150 \mathrm{kWh} \mathrm{m}^{-2}$ on average, which is similar along the entire valley (Fig. 2). The SRAD_sum and TWI_sum were not significant for the right-side sections of the valley, while the mean TWI had a highly positive impact on the number of the species for all the sections studied $(r=0.69)$, and the left and right banks separately $(r=0.72$ and $r=0.63$, respectively).

\section{Correlations between species diversity and topographic attributes}

The topographic attributes exert a different effect on the ecological diversity of flora expressed by the EIVs (Tab. 2). The relationships differed between the valley banks; they were much stronger and more significant for the right side (for all indicators except the $\operatorname{Tr}$ value). The denivelation, which was not significant for the species richness, had a negative impact on the share of species with higher requirements for light $(-0.54<r<-0.80)$, soil humidity $(-0.43<r$ $<-0.70)$, trophy $(r=-0.53)$, acidity $(r=-0.53)$, dispersion $(-0.45<r<-0.59)$, and humus content $(-0.46<r<-0.59)$, especially on the right bank. The mean slope plays a similar role for species diversity. The upslope area affects negatively the $\mathrm{L}, \mathrm{W}, \mathrm{D}$, and $\mathrm{H}$ values $(-0.51<r<-0.65)$, but positively the Tr value $(r=0.48)$ on the left riverside.

The higher the mean total curvature of the right valley slope, the significantly lower the number of species with higher values of the $\mathrm{L}(r=-0.63), \mathrm{W}(r=-0.84), \mathrm{D}(r=$ $-0.51)$, and $\mathrm{H}(r=-0.82)$ indicators. In general, slightly lower correlations were found for the CT_sum: L $(r=$ $-0.47), \mathrm{W}(r=-0.72), \mathrm{D}(r=-0.58)$, and $\mathrm{H}(r=-0.75)$. The SRAD_mean was negatively correlated with the value of $\mathrm{L}$ $(r=-0.48), \mathrm{W}(r=-0.64)$, and $\mathrm{H}(r=-0.65)$ for the right riverbank while the SRAD_sum influenced significantly only the $\operatorname{Tr}$ value on the left bank $(r=0.47)$, i.e. the bank with the northern aspect and its derivatives. A similar situation was observed for the TWI_sum only for the Tr value in the left-side sections $(r=0.47)$. In contrast, the correlations for the TWI_mean were more frequent and higher: $\mathrm{L}(0.37<$ $r<0.48), \mathrm{W}(0.48<r<0.66), \operatorname{Tr}(\mathrm{r}=0.42), \mathrm{R}(r=0.43), \mathrm{D}$ $(r=0.47)$, and $\mathrm{H}(0.46<r<0.66)$.

The RDA analysis revealed topographic attributes of the valley that were the most significant for species richness and diversity (Tab. 2, Fig. 3). The analysis confirmed the positive correlation between the number of species in the sector and its total area and, in particular, with the flat area and the sum and mean TWI (correlation with axis 1). These factors were equally significant, which was evidenced by the length of their vectors. There was a considerably lower correlation between the same axis and the CT_sum. The D value was highly correlated with the TWI_mean and CV_sum. The values of the other EVIs ( $\mathrm{L}, \mathrm{H}, \mathrm{W}, \mathrm{R}$, and $\mathrm{Tr}$ ) were interrelated and positively correlated with axis 2 . Denivelation and upslope area had a reverse vector, and the vectors of the CP_sum and SL_mean were shorter. All the factors were negatively correlated with axis 1 (Fig. 3). The CP_mean, CT_mean, and CT_sum were negatively correlated with axis 2. The alignment of the particular sections of the valley along the axes and vectors of the investigated attributes indicates which attributes exert an impact on the species number and their ecological diversity in each section.

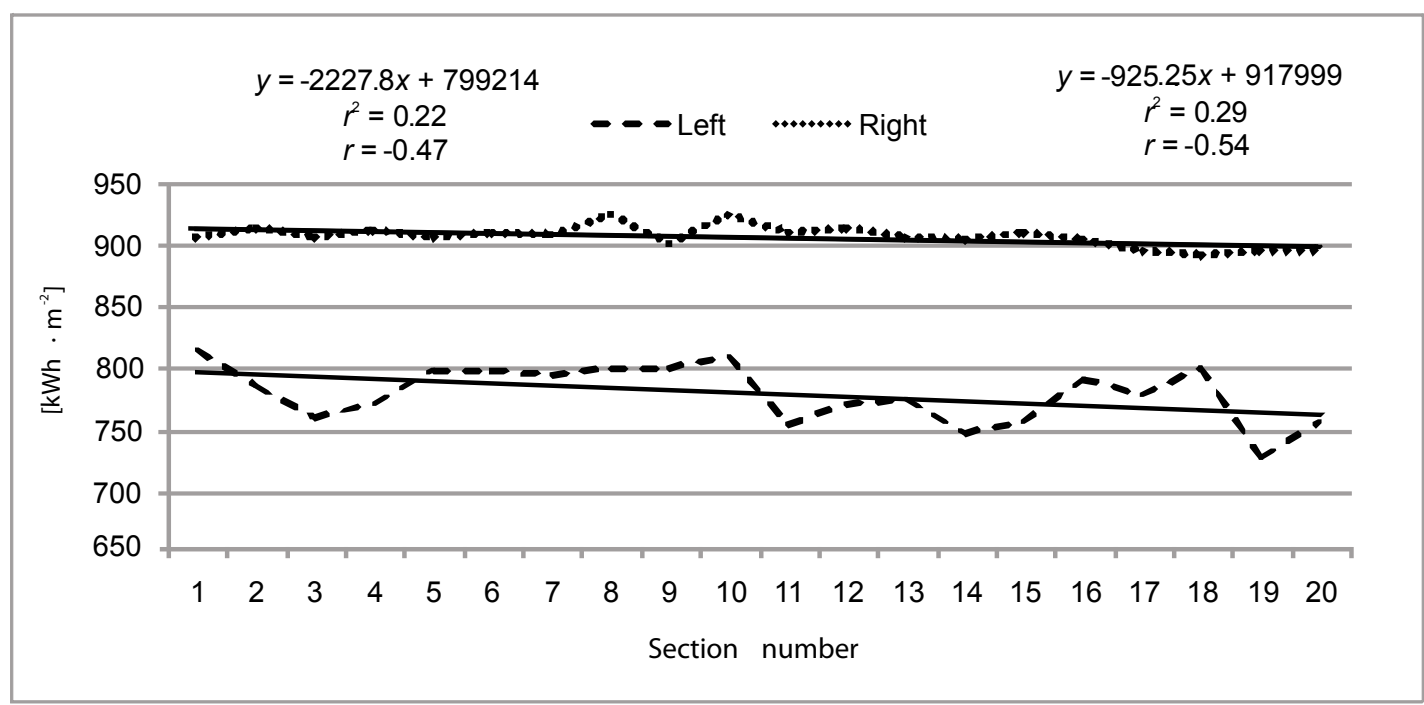

Fig. 2 Amounts of solar energy supplied for the left and right riverbanks and trend line equations for mean SRAD along the Sopot river valley. 


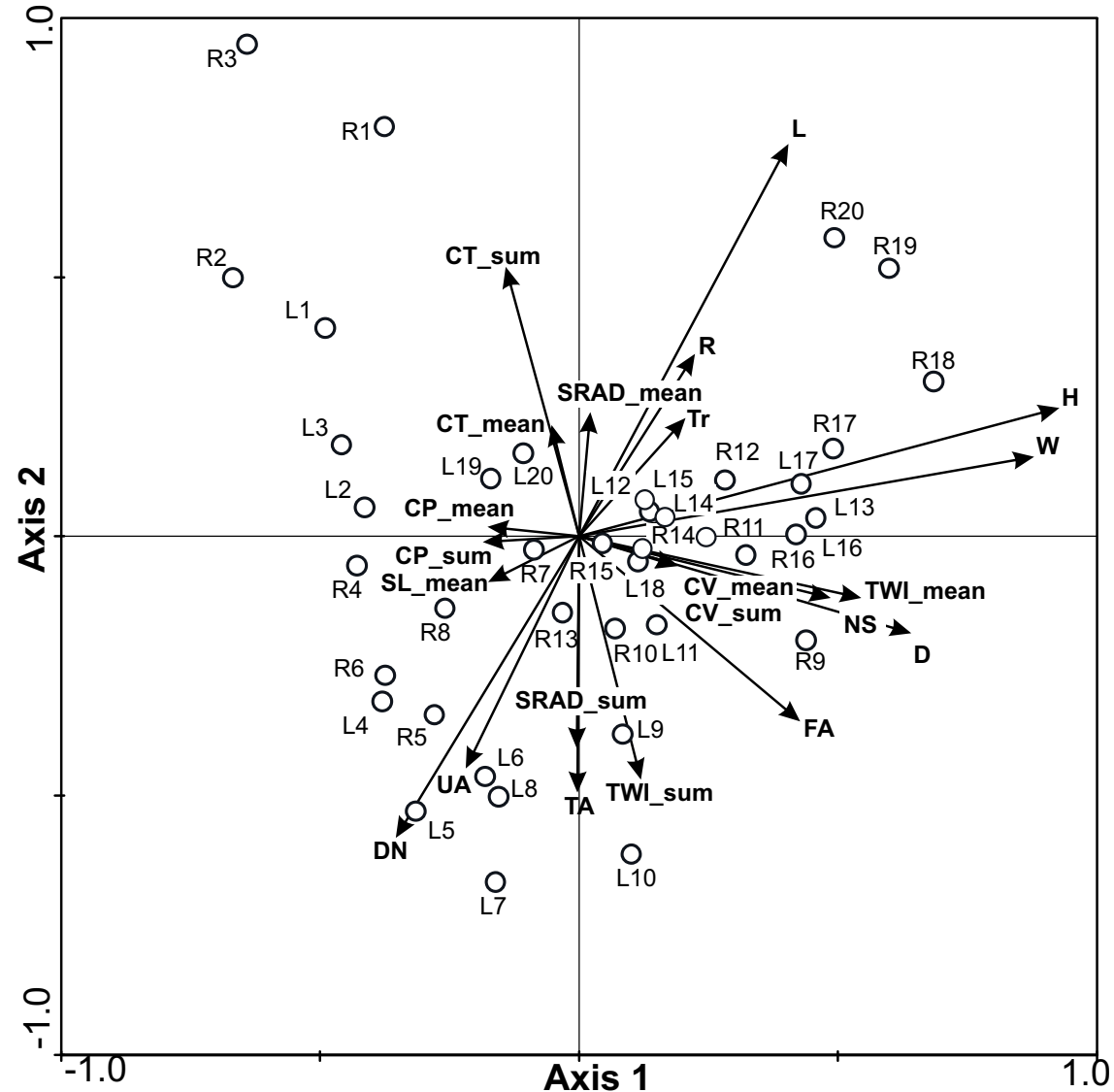

Fig. 3 Ordination diagram showing the result of the RDA for species richness, ecological indicator values and topographic attributes for all sections of the Sopot river valley. Eigenvalues: Axis $1-19.10$, Axis $2-11.22$, Axis $3-7.13$, Axis $4-4.61$. NS - number of species. Remaining abbreviations as in Tab. 2.

The cumulative percentage of ground-floor species and topographic variance explained by the first two RDA axes was $57.4 \%$. For all the variables analyzed for 40 valley sections, the sum values of the Monte Carlo test and forward selection of species-topographic relationships explained
$73.2 \%$ of the variety; for statistically significant variables see Tab. 3. There was a statistically significant relationship between the occurrence of species and the gradients of both RDA canonical axes $(P<0.01)$. F ratio for the first canonical axis was even higher $(4.25 ; P=0.002)$.

Tab. 3 Results of the Monte Carlo permutation tests and forword selection for relations between the ground-floor vegetation, primary and secondary topographic attributes and ecological indicator values in the Sopot river valley.

\begin{tabular}{|c|c|c|c|c|c|c|}
\hline \multirow[b]{2}{*}{ Variable } & \multicolumn{2}{|c|}{ All sections } & \multicolumn{2}{|c|}{ Left bank } & \multicolumn{2}{|c|}{ Right bank } \\
\hline & Lambda A & F ratio & Lambda A & F ratio & Lambda A & F ratio \\
\hline No. of species & 0.08 & $4.19^{\star *}$ & 0.15 & $1.98^{\star *}$ & 0.10 & $2.99^{* *}$ \\
\hline Flat area & & & 0.05 & $1.51^{*}$ & & \\
\hline SRAD_mean & 0.03 & $1.64^{* *}$ & & & & \\
\hline CT_sum & 0.02 & $1.49^{*}$ & & & & \\
\hline CT_mean & 0.02 & $1.40^{*}$ & & & & \\
\hline $\mathrm{H}$ & 0.17 & $7.97^{\star *}$ & 0.20 & $4.60^{* *}$ & 0.22 & $5.07^{\star \star}$ \\
\hline $\mathrm{L}$ & 0.09 & $4.26^{* *}$ & 0.15 & $3.86^{* *}$ & 0.14 & $3.87^{\star *}$ \\
\hline W & 0.04 & $2.78^{\star *}$ & 0.07 & $1.84^{\star \star}$ & 0.07 & $2.12^{\star *}$ \\
\hline $\operatorname{Tr}$ & 0.05 & $2.41^{* *}$ & 0.05 & $1.78^{\star *}$ & 0.06 & $2.02^{\star *}$ \\
\hline $\mathrm{R}$ & 0.03 & $1.43^{*}$ & 0.005 & $1.78^{\star *}$ & & \\
\hline $\mathrm{D}$ & 0.02 & $1.62^{*}$ & & & & \\
\hline
\end{tabular}

Significance level: ${ }^{\star} 0.01<P \leq 0.05 ;{ }^{*} 0.0001<P \leq 0.01$. Explanations as in Tab. 2. 


\section{Ground-floor vegetation on two riverbanks}

The ordination diagrams for both riversides showed varied significance of the topographic attributes analyzed in the individual sections of the valley. For the left riverbank (northern aspect and its derivatives), the following variables are positively correlated with axis 1 (Tab. 3, Fig. 4): CT_sum, W, H, L; a significantly weaker correlation was found for the CP_sum and CT_mean. This is characteristic for sections L11-L15, L17, and L18. The SL_mean and CP_mean are negatively correlated with axis 1 . These factors are important for sections L19 and L20, and less important for L1-L3. The following variables are positively correlated with axis 2 : the number of species, total and flat area, TWI_sum, TWI_mean, and, more weakly, CV_mean. These factors are the most important in the case of sections L9 and L10. The vectors for the Tr and R have a similar length, whereas that for D is considerably longer and similar to vectors $\mathrm{W}$ and $\mathrm{H}$ correlated with axis 1 . With its position, section 16 is related to the group of sectors correlated with axis 1, i.e. L17 and L13 in particular, but section L16 exhibits a significant share of species associated with heavier soil formations, e.g. loams, clayey sands, and clays. The greatest importance for the ground-floor vegetation in sections L6-L8 is attributed to the SRAD_sum, upslope area, denivelation, and SRAD_mean, which are negatively correlated with axis 2 . The aforementioned factors play a lesser role in sections L4 and L5.

For the left bank, the cumulative percentage of groundfloor species and topographic variance explained by the first two RDA axes was 54.9\%. The Monte Carlo test of significance of the first canonical axis showed the value $33.8 \%$. There were 7 statistically significant variables shown by the forward selection of species-topographic relationships (Tab. 3).

On the right side of the valley (southern aspect and its derivatives), the highest positive correlation with axis 1 was observed for the following attributes: denivelation, CT_sum, CT_mean, and SRAD_mean; a weaker correlation was found in the case of the upslope area, SL_mean, CP_mean and CP_sum, SRAD_sum, and total area. These factors have the most substantial role in sections R4-R8 and R13. A negative correlation with axis 1 is exhibited by the $D$ value and TWI_sum. The latter factor seems to have an impact on the ground-floor vegetation in sections R9-R12 and R14-R16. Three EIVs, i.e. L, W, and $\mathrm{H}$ have the strongest correlation with axis 2 and are statistically significant for species diversity. The share of species with high requirements for light, moisture, and humus content exhibits a strong correlation with the TWI_mean, CV_mean, and CV_sum, a slightly weaker relationship with the flat area (section R17). This is particularly important in sections R18-R20. The position of sections R1-R3 in the graph indicates their distinctness from the others. The $\mathrm{Tr}$ and $\mathrm{R}$ values are important for the flora of these sections (Tab. 3, Fig. 5).

The cumulative percentage of ground flora and topographic attributes for the right riverside (southern aspect and its derivatives) explained by the two first RDA axes was 58.8\%. The Monte Carlo test of significance of the first canonical axis showed the value $24.9 \%$. Forward selection of the relationships between the ecological variables revealed 5 statistically significant variables.

\section{Discussion}

Out of the primary topographic attributes [24-26], the following ones seem to be of great ecological relevance for ground-floor vegetation: elevation, slope (surface gradient), aspect (surface orientation), and planar, vertical, and total curvatures. In the present study, we also found other terrain characters to be important for species richness and diversity: the total area of a given section of the river valley, share of the flat area (i.e. floodplain terrace), and share of the upslope area in the sections. Despite the specific zonal toposequence of soil complexes and forest communities in the valley, we found significant differences between the ground-floor vegetation on the opposite riverbanks.

Elevation gradients (denivelations) determine soil variables, species distribution, vegetation production levels, and patterns of disturbance $[3,17,18,42,43]$. Surprisingly, the denivelation of the Sopot river valley (incision into the substratum: mean $=20 \mathrm{~m}, \max =27 \mathrm{~m}$ ) does not alone influence significantly the species richness but shapes the values of all ecological indicators for ground-floor vegetation: L, W, Tr, R, D and H, particularly for the more "sunny" right bank. That terrain attribute was not significant for species richness and ecological variety of flora in another river valley, the Szum river, crossing the escarpment zone of the same highland region, similar in its mountainous character but incised in the bedrock for only $10 \mathrm{~m}$ on average; max $=15 \mathrm{~m}$ [14].

We found other primary attributes to be significantly important for both richness and diversity of the ground-floor vegetation. The species richness was positively correlated with the total area of a given section and first of all with the proportion of the flat area for the entire study area. The width of the floodplain terrace seems to be of great importance for the species richness because of the presence of the richest hygrophilous and nitrophilous vegetation, i.e. ash-alder forests Fraxino-Alnetum and bog alder forests Ribeso nigri-Alnetum. Their occurrence is promoted, from the riverbed side, by sedimentation of heavier and hence more nutrient-rich mineral formations: loams, clayey sands, heavy and silty clays [34,35]. This is also evidenced by significant correlations between the flat area and some EIVs: $\mathrm{Tr}, \mathrm{D}$, and $\mathrm{H}$; the intercorrelations are noticeably higher for the right riverbank.

Significant negative correlations were found for the mean slope in the individual valley sections and all of the study EIVs: L, W, Tr, R, D, and H. The correlations were usually higher for the right riverbank, which is characterized by southern aspect and its derivatives. The upslope area also influences the decrease in the share of species with higher requirements for light, humidity, heavier soil formations, and humus content. Greater slopes, higher insolation, and lower humidity offer less favorable conditions for accumulation and humification of organic matter. Soils in such conditions are more acidic and poorer podzolics overgrown with different coniferous forests, first of all upland mixed fir forest Abietetum polonicum $[11,12,35]$.

On the right-side bank, a positive influence of vertical curvatures on the species number and the increase in species with higher requirements for light was noted. In contrast, 


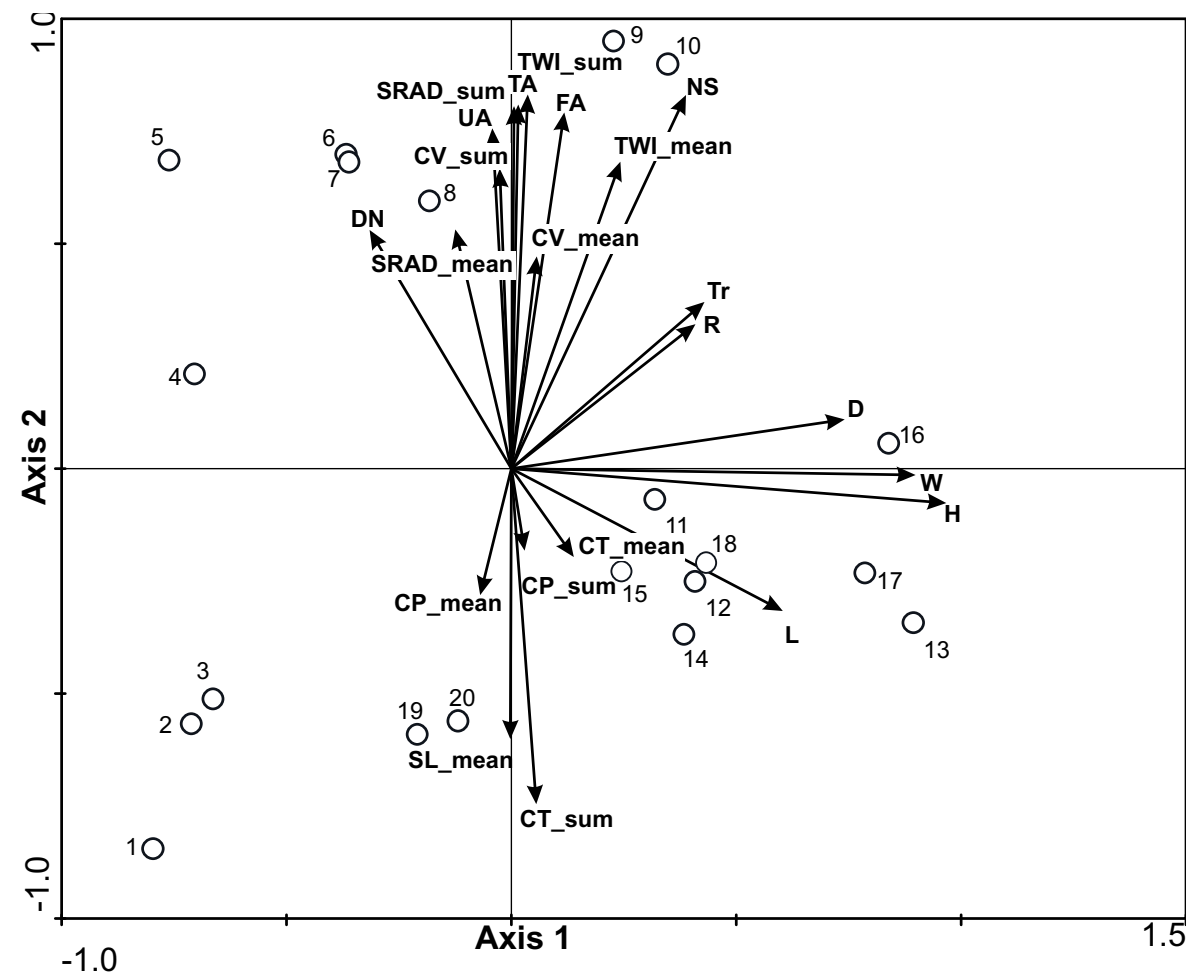

Fig. 4 Ordination diagram showing the result of the RDA for species richness, ecological indicator values and topographic attributes for the left-side sections of the Sopot river valley. Eigenvalues: Axis $1-21.32$, Axis $2-16.93$, Axis $3-9.50$, Axis $4-7.10$. Abbreviations as in Tab. 2 and Fig. 3.

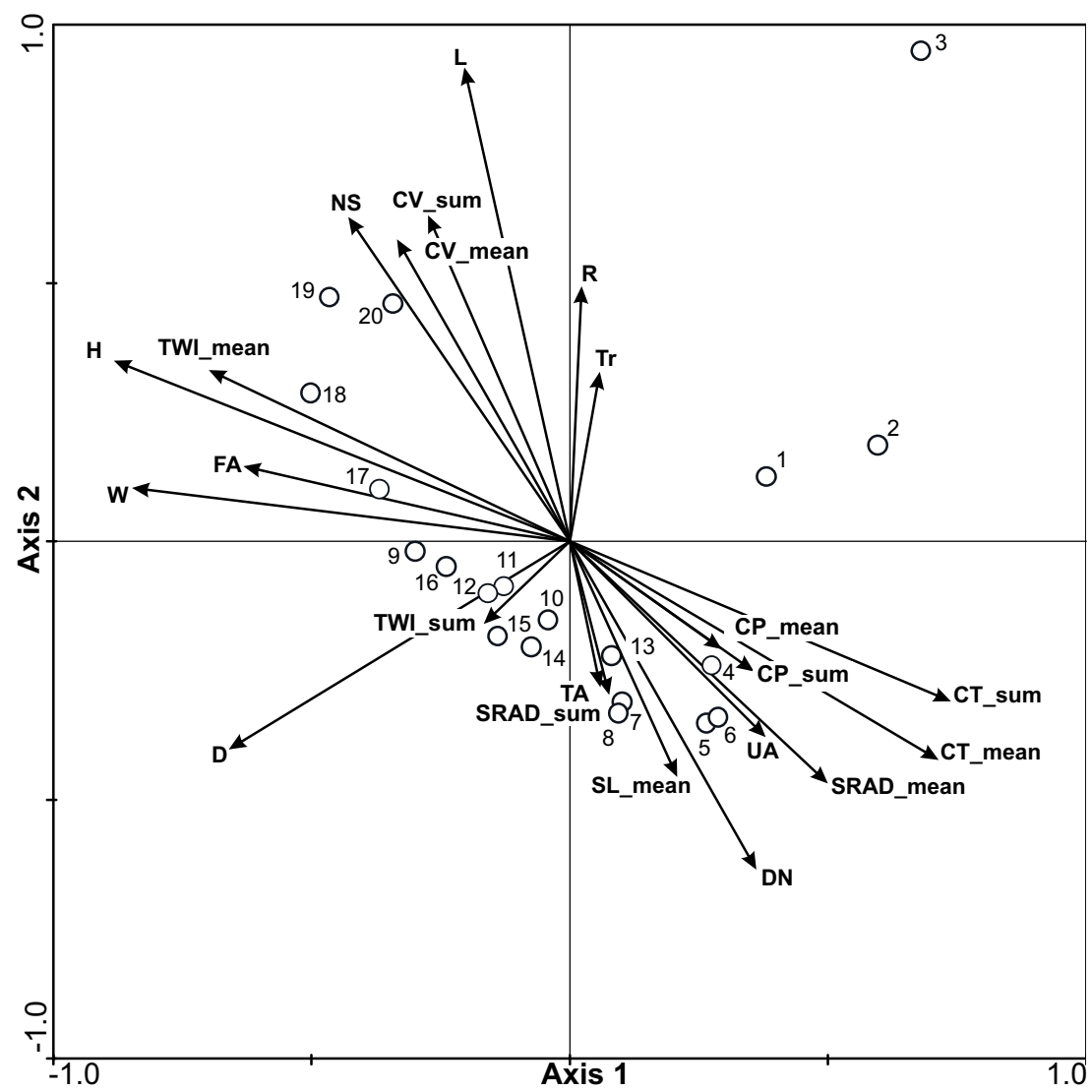

Fig. 5 Ordination diagram showing the result of the RDA for species richness, ecological indicator values and topographic attributes for the right-side sections of the Sopot river valley. Eigenvalues: Axis $1-24.92$, Axis $2-15.11$, Axis $3-10.70$, Axis $4-8.11$. Abbreviations as in Tab. 2 and Fig. 3. 
the total curvatures contributed significantly to the decrease in the share of species with higher $\mathrm{L}, \mathrm{H}, \mathrm{D}$, and $\mathrm{H}$ values. This indicates that the slopes of the valley are dominated by convex rather than concave forms. Simultaneously, we also found negative correlations between the planar curvature and the species number, and the $\operatorname{Tr}$ and $\mathrm{R}$ values. This implies that the planar curvature of the contour lines has more "ridges" than "valleys", which promotes divergence of flowing water over the convergence of water [24-26]. This situation, locally together with the narrow terrace and water velocity, reduces the repository role of the river, thereby leading to reduction of the nutrient content and reaction of soil $[4,5,7]$.

The SRAD values are significantly correlated with the number of species and diversity of ground-floor vegetation in the study river valley. This secondary topographic attribute is highly variable from place to place due to changing slope and aspect $[17,18,44]$. In the present study, the decisive condition shaping the energy amounts delivered for both riverbanks was the almost parallel course of the valley in a greater part of the analyzed fragment. The disproportion is on average $150 \mathrm{kWh} \mathrm{m}^{-2}$, in favor of the right-side section. That is approximately one fifth of the total amounts of solar energy reaching the ground-floor layer during the vegetation season on the left-site bank. On the right riverside, the mean SRAD has a negative impact on the species number and share of species with higher light, humidity, and organic matter content requirements. In turn, on the more "shiny" left riverside, the sum SRAD promotes highly the rise of species richness and the trophy level of soils.

Since exact measurement of the water regime is very difficult, the TWI derived from DEM is commonly used in analyses of relationships between abiotic and biotic environmental characters. The TWI correlates well with soil attributes such as horizon depth, groundwater table, silt and organic matter contents, and thereby serves as a good indicator of habitat productivity $[18,23,42,45,46]$. In our

\section{Acknowledgments}

The authors are grateful to two anonymous reviewers for their criticism and valuable comments on the manuscript and to Prof. Józef Superson, for discussion on geomorphology problems. We would also like to thank Mrs. Anna Zoń, M.A., who has improved our English. This research was supported financially by the Faculty of Biology and Biotechnology, and Faculty of Earth Sciences and Spatial Management, Maria Curie-Skłodowska University in Lublin, Poland.

\section{Authors' contributions}

The following declarations about authors' contributions to the research have been made: concept of the study: BC; field and laboratory work: BC; statistical analyses: AR, ŁC; GIS and DEM: $Ł C$; writing the manuscript: BC.

\section{Competing interests}

No competing interests have been declared.

\section{References}

1. Kolasa J, Rolle CD. Introduction. The heterogeneity of heterogeneity: a glossary. In: Kolasa J, Pickett STA, editors. Ecological heterogeneity. New York, NY: Springer-Verlag; 1999. p. 1-23.

2. Gregory SV, Swanson FJ, McKee WA, Cummins KW. An ecosystem perspective of riparian zones: focus on links between land and water. Bioscience. 1991;41(8):540-551. research, the TWI, particularly its mean values, is significantly positively correlated with the species abundance and all the EIVs studied. As a rule, the TWI was more important for the ground flora on the right (more "sunny") than the left (more "shiny") riverbank, with the exception of the Tr value.

Among the EIVs, the $\mathrm{R}$ value seems to be most frequent subject of studies. However, some authors found during field measurements that $\mathrm{pH}$ values for some ecological groups of species were different than those expected from Ellenberg's scale, which strongly limits the use of the $\mathrm{R}$ values and requires re-calibration [28-30,33,47]. The well-known influence of soil acidity and calcium content on species occurrence [33] may also apply to the study area due to the presence of the $\mathrm{Ca}$-rich formations of various origins and age (2.5-89\% of $\mathrm{CaCO}_{3}$ content). The diverse water-bearing horizons of these formations result in approximately a ninefold differentiation of water mineralization [11,35].

In conclusion, we have to stress that the GIS, DEM, and multivariate ordination methods have become a useful tool for detection of species richness and distribution of their ecological groups in correlation with primary and secondary topographic attributes of a given terrain, including riparian landscapes. We have also proved that the EIV system, which has been widely applied for modeling plant distribution at large spatial scales, i.e. on the global or regional levels, may be used on a local level, e.g. in a minor river valley and its particular banks. In the light of our study, the course of the river valley which determines the differentiation in slope aspects and, in consequence, between the amount of solar radiation reaching the ground-floor vegetation, does not change the species richness on a more "sunny" and more "shiny" riverbank. However, this factor "cooperating" with other topographic attributes may significantly differentiate the shape of herb species showing various requirements for basic habitat resources: light, moisture, soil trophy, reaction, dispersion, and organic matter content.

3. Lyon J, Sagers CL. Structure of herbaceous plant assemblages in a forested riparian landscape. Plant Ecol. 1998;138:1-16.

4. Werner KJ, Zedler JB. How sedge meadows, soils, microtopography, and vegetation respond to sedimentation. Wetlands. 2002;22(3):451466. http://dx.doi/org/10.1672/0277-5212(2002)022[0451:HSMSM A] 2.0.CO;2

5. Francis RA, Tibaldeschi P, McDougall L. Fluvially-deposited large wood and riparian plant diversity. Wetlands Ecol Manage. 2008;16(5):371-382. http://dx.doi/org/10.1007/s11273-007-9074-2

6. Duru M, Ansquer P, Jouany C, Theau JP, Cruz P. Comparison of methods for assessing the impact of different disturbances and nutrient conditions upon functional characteristics of grassland communities. Ann Bot. 2010;106(5):823-831. http://dx.doi.org/10.1093/aob/mcq178

7. Jolley RL, Lockaby BG, Cavalcanti GG. Changes in riparian forest composition along a sedimentation rate gradient. Plant Ecol. 2010;210(2):317-330. http://dx.doi/org/10.1007/s11258-010-9759-0

8. Angiolini C, Nucci A, Frignani F, Landi M. Using multivariate analyses to assess effects of fluvial type on plant species distribution in a Mediterranean river. Wetlands. 2011;31(1):167-177. http://dx.doi/ org/10.1007/s13157-010-0118-7

9. Tabacchi E, Correll DL, Hauer R, Pinay G, Planty-Tabacci AM, Wissmar RC. Development, maintenance and role of riparian vegetation in the river landscape. Freshw Biol. 1998;40(3):497-516. http://dx.doi/ org/10.1046/j.1365-2427.1998.00381.x 
10. Decocq G. Patterns of plant species and community diversity at different organization levels in a forested riparian landscape. J Veg Sci. 2002;13(1):91-106. http://dx.doi/org/10.1111/j.1654-1103.2002. tb02026.x

11. Czarnecka B, Janiec B. Przełomy rzeczne Roztocza jako modelowe obiekty w edukacji ekologicznej. Lublin: Maria Curie-Skłodowska University Press; 2002.

12. Czarnecka B, Janiec B. Krajobrazy roślinne jako wyraz naturalnych i antropogenicznych przemian środowiska małych dolin rzecznych Roztocza. Problemy Ekologii Krajobrazu. 2006;16:171-184.

13. Dunn WC, Milne BT, Mantilla R, Gupta VK. Scaling relation between riparian vegetation and stream order in the Whitewater River Network, Kansas, USA. Landsc Ecol. 2011;26(7):983-977. http://dx.doi/ org/10.1007/s10980-011-9622-2

14. Czarnecka B, Chabudziński Ł. Assessment of flora diversity in a minor river valley using ecological indicator values, geographical information systems and digital elevation models. Centr Eur J Biol 2014;9(2):220-231. http://dx.doi/org/10.2478/s11535-013-0263-0

15. Muller E. Mapping riparian vegetation along rivers: old concepts and new methods. Special issue: geographic information systems and remote sensing in aquatic botany. Aquatic Bot. 1997;58(3-4): 411-437. http://dx.doi.org/10.1016/S0304-3770(97)00049-1

16. Tappeiner U, Tasser E, Tappeiner G. Modelling vegetation patterns using natural and anthropogenic influence factors: preliminary experience with a GIS based model applied to an Alpine area Ecol Modell. 1998;113(1-3):225-237. http://dx.doi.org/10.1016/ S0304-3800(98)00145-8

17. Pfeffer K, Pebesma EJ, Burrough PA. Mapping alpine vegetation using vegetation observations and topographic attributes. Landsc Ecol. 2003;18(8):759-776. http://dx.doi.org/10.1023/ B:LAND.0000014471.78787.d0

18. Fitterer JL, Nelson TA, Coops NC, Wulder MA. Modelling the ecosystem indicators of British Columbia using Earth observation data and terrain indices. Ecol Indic. 2012;20:151-162. http://dx.doi. org/10.1016/j.ecolind.2012.02.024

19. Ter Braak CJF, Šmilauer P. CANOCO reference manual and CanoDraw for Windows. User's guide: software for canonical community ordination, Version 4.5. Ithaca, NY: Microcomputer Power; 2002.

20. Lepš J, Šmilauer P. Multivariate analysis of ecological data using Canoco. Cambridge: Cambridge University Press; 2003.

21. Seidling W. Ground floor vegetation assessment within the intensive (level II) monitoring of forest ecosystems in Germany: chances and challenges. Eur J For Res. 2005;124(4):301-312. http://dx.doi. org/10.1007/s10342-005-0087-1

22. Petrik P, Wild J. Environmental correlates of the patterns of plan distribution at the meso-scale: a case study from Northern Bohemia (Czech Republic). Preslia. 2006;78:211-234.

23. Kopecký M, Čižkova Š. Using topographic wetness index in vegetation ecology: does the algorithm matter? Appl Veg Sci. 2010;13(4):450-459. http://dx.doi.org/10.1111/j.1654-109X.2010.01083.x

24. Willson JP, Gallant JC, editors. Terrain analysis. Principles and applications, New York, NY: John Wiley and Sons; 2000.

25. Kraak MJ, Ormeling F. Cartography. Visualisation of geospatial data. Glasgow: Bell and Brain Ltd.; 2003

26. Urbański J. GIS w badaniach przyrodniczych [Internet]. 2012 [cited 2015 Mar 16]. Available from: http://ocean.ug.edu.pl/ oceju/CentrumGIS/dane/GIS_w_badaniach_przyrodniczych_12_2.pdf

27. Ellenberg H. Zeigerwerte der Gefäßpflanzen Mitteleuropas. Scr Geobot. 1974;9:9-160

28. Ertsen ACD, Alkemade JRM, Wassen MJ. Calibrating Ellenberg indicator values for moisture, acidity, nutrient availability and salinity in the Netherlands. Plant Ecol. 1998;135:113-124.

29. Wamelink GWW, Joosten V, van Dobben HF, Berendse F. Validity of Ellenberg indicator values judged from physico-chemical field measurements. J Veg Sci. 2002;13(2):269-278. http://dx.doi. org/10.1111/j.1654-1103.2002.tb02047.x

30. Lawesson JE, Fosaa AM, Olsen E. Calibration of Ellenberg indicator values for the Faroe Islands. Appl Veg Sci. 2003;6(1):53-62. http:// dx.doi.org/10.1111/j.1654-109X.2003.tb00564.x

31. Crosti R, de Nicola C, Fanelli G, Testi A. Ecological classification of beech woodlands in the Central Apennine through frequency distribution of Ellenberg indicators [Internet]. Ann Bot (Roma). 2010 [cited 2015 Mar 16]. Available from: http://ojs.uniromal.it/index.php/ Annalidibotanica/article/view/9112/9052

32. Balkovič J, Kollár J, Šimonovič V. Experience with using Ellenberg’s R indicator values in Slovakia: oligotrophic and mesotrophic submontane broad-leaved forests. Biologia. 2012;67(3):474-482. http://dx.doi. org/10.2478/s11756-012-0027-8

33. Schaffers AP, Sýkora KV. Reliability of Ellenberg indicator values for moisture, nitrogen and soil reaction: a comparison with field measurements. J Veg Sci. 2000;11(2):225-244. http://dx.doi. org/10.2307/3236802

34. Czarnecka B, Janiec B. Factors affecting the distribution and properties of forest soils in river breaks of Roztocze. Acta Agrophys. 2001;50:81-93.

35. Janiec B, Czarnecka B. The "Czartowe Pole" landscape reserve in Roztocze (SE Poland) in the light of interdisciplinary research. Ekologia (Bratislava). 2001;20(4 suppl):222-232.

36. European Commission 2007. Interpretation manual of European Union habitats. Eur 27. DG Environment.

37. Dobrzański B, Uziak S, Klimowicz Z, Melke J. Badanie gleb w laboratorium i w polu. Lublin: Maria Curie-Skłodowska University Press; 1992.

38. Sapek A, Sapek B. Metody analizy chemicznej gleb organicznych. Falenty: IMUZ; 1997.

39. Hengl T. Finding the right pixel size. Comput Geosci. 2006;32(9):12831298. http://dx.doi.org/10.1016/j.cageo.2005.11.008

40. Bergès L, Gègout JC, Franc A. Can understory vegetation accurately predict site index? A comparative study using floristic and abiotic indices in sessile oak (Quercus petraea Liebl.) stands in northern France. Ann For Sci. 2006;63(1):31-42. http://dx.doi.org/10.1051/ forest:2005091

41. Zarzycki K, Trzcińska-Tacik H, Różański W, Szeląg Z. Wołek J Korzeniak U. Ecological indicator values of vascular plants of poland. Biodiversity of Poland 2. Kraków: W. Szafer Institute of Botany, Polish Academy of Sciences; 2002.

42. Dorner B, Lertzman K, Fall J. Landscape pattern in topographically complex landscapes: issues and techniques for analysis. Landsc Ecol. 2002:17(8):729-743. http://dx.doi.org/10.1023/A:1022944019665

43. Kumar L, Skidmore AK, Knowles E. Modelling topographic variation in solar radiation in a GIS environment. Int J Geogr Inf Sci. 1997;11(5):475-497. http://dx.doi.org/10.1080/136588197242266

44. Moore DM, Lees BG, Davey SM. A new method for predicting vegetation distributions using decision tree analysis in a geographic information system. Environ Manage. 1991;15(1):59-71. http://dx.doi. org/10.1007/BF02393838

45. Sørensen R, Zinko U, Seibert J. On the calculations of the topographic wetness index evaluation of different methods based on field observation. Hydrol Earth Syst Sci. 2006;10(1):101-112. http://dx.doi. org/10.5194/hess-10-101-2006

46. Franklin J. Predictive vegetation mapping: geographic modelling of biospatial patterns in relation to environmental gradients. Prog Phys Geogr. 1995;19(4):474-499. http://dx.doi. org/10.1177/030913339501900403

47. Feldmeyer-Christe E, Ecker K, Küchler M, Graf U, Waser L. Improving predictive mapping in Swiss mire ecosystems through re-calibration of indicator values. Appl Veg Sci. 2007;10(2):183-192. http://dx.doi. org/10.1111/j.1654-109X.2007.tb00516.x 